\title{
THE PRODUCTION OF KNOWLEDGE IN NURSING IN THE BRIC COUNTRIES: A BIBLIOMETRIC STUDY
}

\author{
Luiz Carlos Santiago ${ }^{1}$ Lucilia Feliciano Marques di Carlantonio ${ }^{2}$
}

\footnotetext{
${ }^{1}$ Post-doctorate in Nursing. Adjunct Professor of the Department of Fundamentals of Nursing, of the Escola de Enfermagem Alfredo Pinto (EEAP), Universidade Federal do Estado do Rio de Janeiro (UNIRIO). Rio de Janeiro, Brazil. E-mail: luisolitrio@gmail.com

2 Master's student on the Postgraduate Program in Nursing, EEAP/UNIRIO. Rio de Janeiro, Brazil. E-mail: marques_lucilia@ yahoo.com.br
}

ABSTRACT: The electronic databases and tools for promoting knowledge make scientific and technological development possible in the areas of health and of nursing. This bibliometric study aimed to map the indicators regarding nursing, published in 2012, in the SJR database, by the BRIC countries. These countries' production in nursing was analyzed comparatively in relation to documents, citations, h-index and international collaboration. The results show: 1,039 articles published in Brazil, nine articles published in Russia, 212 articles published in India, and 541 articles published in China, in 2012, and evidence the importance of these centers of research and of disseminating knowledge.

DESCRIPTORS: Nursing. Knowledge. Technology. Bibliometrics.

\section{A PRODUÇÃO DO CONHECIMENTO EM ENFERMAGEM PELOS PAÍSES DO BRIC: ESTUDO BIBLIOMÉTRICO}

RESUMO: As bases de dados eletrônicas são ferramentas promotoras de conhecimento e possibilitam o desenvolvimento científico e tecnológico na área da saúde e da enfermagem. Este estudo bibliométrico teve como objetivo mapear os indicadores sobre enfermagem, publicados no ano de 2012 na base de dados SJR, pelos países do BRIC. A produção de enfermagem desses países foi analisada de forma comparativa ao que se refere: documentos, citações, índice H e colaboração internacional. Os resultados mostram: 1039 artigos publicados no Brasil, nove artigos publicados na Rússia, 212 artigos publicados na Índia e 541 artigos publicados na China, no ano de 2012. Evidenciam a importância desses centros de pesquisa e de divulgação do conhecimento.

DESCRITORES: Enfermagem. Conhecimento. Tecnologia. Bibliometria.

\section{LA PRODUCCIÓN DE CONOCIMIENTOS EN ENFERMERÍA POR BRIC: ESTUDIO BIBLIOMÉTRICO}

RESUMEN: Las bases de datos electrónicas son herramientas para promover el conocimiento y permitir el desarrollo científico y tecnológico en salud y enfermería. Este estudio bibliométrico era situar los indicadores en Enfermería, publicado en 2012 sobre la base de datos SJR, los países BRIC. La producción de amamantar a estos países se analizó de manera comparativa a respetar: documentos, citas, H-índice y la colaboración internacional. Los resultados muestran: artículos publicados en Brasil en 1039, nueve artículos publicados en Rusia, 212 artículos publicados en la India y 541 artículos publicados en China en el estudio en el año 2012 confirmó la importancia de estos centros de investigación y difusión del conocimiento.

DESCRIPTORES: Enfermería. Conocimiento. Tecnologia. Bibliométrico. 


\section{INTRODUCTION}

The Internet is a global network of computers, growing exponentially, and aggregating an increasing number of networks and users, having passed the level of 200 million. This context makes it possible to value information through the increasingly significant use of technology. ${ }^{1}$

The number of users is extremely high, as is the production of knowledge which, with this new perspective, has established an impact and become a determinant for our social and professional behaviors. We live in a civilization whose generative and broadcasting capacity, in relation to scientific research, produces innumerable models for argumentation in the condition of scientifictechnological product, of widely-varying origins.

The Internet has represented an essential environment for this, and imposes on each one of us the appropriate critical posture for spreading information, at the level of both our day-to-day and, mainly, in the routine of our professional practice.

Attention is drawn to information as a symbolic and essential element of contemporary civilization, and the following assertion is established regarding it: "[...] information is increasingly gaining value and directing societies' lives... It is formed by data and requires organization, structuring and representation through signs and symbols. Through the set of this information, man establishes and elaborates his knowledge, necessary for his survival, in a process of constant change $[\ldots]^{\prime \prime}$. 2:14

Hence, through the technology used in the electronic databases, the diffusion and evolution of scientific knowledge occurs, allowing distinct opportunities for discoveries which bring together different scientific disciplines.

Significant repercussions in the human process of living are being brought together through the advances of science and technology. In reflecting on the human lifecycle, it becomes essential to identify the implications of these advances in the element of health care. ${ }^{3}$

Considering this fact, concern is necessary regarding the set of scientific and technological productions which are underway in Brazilian and international nursing, reflecting on the four countries considered as emerging: Brazil, Russia, India and China. These have the economic potential to overtake the great powers of the world in a period of, at the most, 50 years.
Economists and political scientists initially considered these countries to be a group with economic characteristics in common; however, in 2006, they came to have a classification so as to obtain international visibility. In the $61^{\text {st }}$ General Assembly of the United Nations, Brazil, Russia, India and China decided to formalize the expression "BRIC", a diplomatic character which led to the undertaking of collective economic actions on the part of these countries, as well as to greater communication between them. In 2011, the Republic of South Africa was officially incorporated into the BRIC Group, which then came to be called BRICS. ${ }^{4}$

With more than $21 \%$ of world GDP, they are currently considered to be the group of countries in ascension. They represent $42 \%$ of the world population and $45 \%$ of the workforce, and as a result of this have acquired the highest purchasing power in the world. They have also been emphasized due to their national wealth and the favorable conditions which they present for exploring these. ${ }^{4}$

As a result of this, it is possible to perceive this group's economic and political importance, as it is possible also to foresee rivalry between the BRIC countries, the USA and the European Union. This being the case, questions and reflections on these countries' production of scientific-technical knowledge have grown, such that we may be able to bring together elements and support which can configure a combination of arguments regarding the international contribution in scientific nursing production produced by the BRIC countries.

For this, an organization and classification are necessary of what is being achieved by nursing in these emerging countries, in terms of academic research, such that, indeed, we may have relevance regarding our own state-of-the-art, that is, that which we can consider as assertions derived from our research which establish standards of technical-scientific information which have impacts and repercussions on our profession.

As a result, this article will emphasize how this scientific knowledge referent to nursing is being produced and published by the BRIC countries, using some bibliometric indicators as an instrument.

As a result, the present study aimed to analyze comparatively the scientific and technological production undertaken by nursing in Brazil, Russia, India, and China (the BRIC countries) in 2012. 


\section{MATERIAL AND METHOD}

This is a bibliometric study with a quantitative character. Bibliometrics can be defined as: "[...] the study of the quantitative aspects of the production, dissemination and use of the information recorded. Bibliometrics develops patterns and mathematical models for measuring these processes, using its results to elaborate forecasts and support decision-making". 5:134

Through the quantitative study of publications, bibliometrics analyzes the development of the technical or scientific activity, with the aim of developing quality indicators. These indicators may be expected to be the parameters for evaluating any activity. ${ }^{6}$

In order to undertake this work, the SJR database (SCImago Journal \& Country Rank) was used, a portal for journals and scientific indicators of rising developing countries, which uses information contained in the Scopus database since $1996 .^{7}$

A study was undertaken on the SJR site, selecting nursing as the discipline, encompassing all the topics of this issue in 2012, pertinent to the countries which make up the BRIC bloc: Brazil, Russia, India and China. As a result, tables were made available referent to what was published in the area of Nursing in 2012, enabling comparison between the above-mentioned countries. In the discussion, we analyze each comparative table, seeking a holistic view of the data.

Due to the mechanisms provided by the SJR database used by us to undertake the research, which limit use to only four countries for comparing data, we opted to work with the initial composition of the BRIC Group: Brazil, Russia, India and China, excluding South Africa from the research, as we believe that it is more appropriate, at this time, to understand the process of production of scientific knowledge referent to nursing based on the initial composition of the BRIC bloc. In the future, we believe it will be of extreme importance to analyze the nursing production of the BRICS countries, in this way including the contribution of South Africa.

So as to obtain data exclusively from the area of nursing, nursing was defined as the discipline in all the analyses. In the organizing of the data, the following variables were established: discipline (nursing); all the categories of the discipline (advanced and specialized nursing, assessment and diagnosis, care planning, community and home care, critical care nursing, emergency nursing, fundamentals and skills, gerontology, issues ethics and legal aspects, leadership and management, LPN and LVN, maternity and midwifery, medical-surgical nursing, nurse assisting, nursing (miscellaneous), nutrition and dietetics, oncology (nursing), pathophysiology, pediatrics, pharmacology (nursing), psychiatric mental health, review and exam preparation, research and theory); the BRIC countries (Brazil, Russia, India and China), and the years 1996 - 2012. All this information was stored on a spreadsheet. ${ }^{7}$

The research covered the production and the scientific indicators for the area of nursing, published in 2012. Data collection was undertaken in October - December 2013. The data selected were raised in accordance with bibliometric data relative to: documents, citations in documents, citations, self-citations, citations by document, citations of self-citations by document, h-index, percentage of documents cited and International collaboration.

Based on this corpus, the above were analyzed in accordance with bibliometric data relative to: documents, citations, h-index, and international collaboration. The data were obtained based on access to each report produced through the SJR database, comparing the BRIC countries (Brazil, Russia, India and China).

\section{RESULTS AND DISCUSSION}

For 2012, referent to the discipline of nursing, the following were identified: 1,039 articles published in Brazil, nine articles published in Russia, 212 articles published in India and 541 articles published in China. We evidence this event in Table 1, which reports the scientific production in accordance with each country mentioned in the BRIC bloc.

In this way, the sample evidences that Brazil was the country which published most in 2012, followed by China, although with a large discrepancy. In analyzing this fact, we emphasize the need to broaden the bases of academic research and of technological innovations; in addition to the system of primary, middle and higher education, which need transformation, abandoning the informative component for the formative, becoming a means of preparation for the job market, which is highly subordinate to continuous learning. ${ }^{8}$ 
Table 1 - Report of the scientific production in nursing, by country participating in the BRIC bloc, 2012

\begin{tabular}{lcccc}
\hline Year & Brazil & Russia & India & China \\
\hline 1996 & 12 & 3 & 10 & 10 \\
1997 & 15 & 2 & 18 & 8 \\
1998 & 12 & 2 & 13 & 9 \\
1999 & 16 & 3 & 23 & 11 \\
2000 & 16 & - & 25 & 9 \\
2001 & 18 & 2 & 20 & 14 \\
2002 & 28 & 5 & 48 & 15 \\
2003 & 31 & 3 & 36 & 17 \\
2004 & 65 & 4 & 33 & 29 \\
2005 & 89 & 4 & 64 & 36 \\
2006 & 312 & 10 & 85 & 367 \\
2007 & 462 & 6 & 121 & 395 \\
2008 & 533 & 6 & 123 & 417 \\
2009 & 664 & 11 & 182 & 436 \\
2010 & 861 & 15 & 165 & 504 \\
2011 & 964 & 10 & 222 & 473 \\
2012 & 1039 & 9 & 212 & 541 \\
\hline
\end{tabular}

Source: SJR - SCImago Journal \& Country Rank.

With the rise in postgraduate programs in Brazil, a significant growth has occurred in knowledge, these being closely interlinked. ${ }^{9-10}$ Through the postgraduate courses, Brazil has sought to solidify scientific bases and to train human resources so as to attempt to resolve regional and national impasses. The hope is to achieve such goals through the qualification of the researchers, relying on the training system. This fact requires a methodological expertise for testing them, making them disseminators for the development of new researchers and the production generated, endorsed by external assessors of the national and international context. ${ }^{11}$

In observing the citations referent to nursing production in 2012, China (181) led the comparative ranking between the countries which make up the BRIC bloc. It is followed by Brazil (115), followed by, with a significant difference, India (27) and Russia (3). Below, table 2, which relates scientific citations according to each country in the BRIC bloc, provides examples.
Table 2 - Report of the scientific nursing citations. Citations by country participating in BRIC, 2012

\begin{tabular}{lcrcc}
\hline Year & Brazil & Russia & India & China \\
\hline 1996 & 216 & 59 & 142 & 115 \\
1997 & 642 & 82 & 211 & 300 \\
1998 & 472 & 245 & 256 & 364 \\
1999 & 347 & 28 & 343 & 164 \\
2000 & 401 & 0 & 328 & 195 \\
2001 & 232 & 26 & 521 & 232 \\
2002 & 566 & 32 & 572 & 325 \\
2003 & 926 & 50 & 553 & 215 \\
2004 & 1519 & 112 & 759 & 502 \\
2005 & 1261 & 81 & 595 & 865 \\
2006 & 1951 & 172 & 458 & 1141 \\
2007 & 2069 & 24 & 732 & 1562 \\
2008 & 1909 & 19 & 648 & 1113 \\
2009 & 2397 & 47 & 799 & 1960 \\
2010 & 1385 & 72 & 442 & 988 \\
2011 & 684 & 16 & 387 & 432 \\
2012 & 115 & 3 & 27 & 181 \\
\hline
\end{tabular}

Source: SJR - SCImago Journal \& Country Rank.

We observed a large difference in 2011, when Brazil presented 684 citations and China, 432 . The peak of citations occurred in 2009, a period in which Brazil presented 2,397 articles, and China, 1,960 . We are facing a rise in academic works published in journals, referent to Brazilian scientific production; however, in analyzing the quality of these works, it remains inadequate.

In the period 2001 - 2011, Brazil went from $17^{\text {th }}$ to $13^{\text {th }}$ position worldwide in the number of articles published. Brazilian researchers published 49,664 articles in 2011, equivalent to 3.5 times the production of $2001(13,846)$. On the other hand, it dropped sharply in the rankings for the quality of the scientific works, evaluated by the number of times that each study was cited by other scientists.

Researchers believe that this fact occurs due to a policy of openness for national scientific journals of countries such as Brazil, China and India. It also stands out that works from Brazilian scientific journals have little impact, an observation analyzed in 2001, when only 16 Brazilian journals received one or more citations per article. ${ }^{12}$ 
Among these periodicals, emphasis is placed on the journal "Memórias do Instituto Oswaldo Cruz", which received a score of 2.5 , obtaining the greatest impact among the Brazilian journals. ${ }^{13}$ The current higher education policy in Brazil places pressure on researchers to publish more, which drives publications which are not well elaborated, weighing negatively on the quality. ${ }^{14}$

It should be highlighted that it is not only the fact that Brazilian researchers end up publishing content which is little valued that undermines the impact of Brazilian science in the world. We have foreign authorship, which is today responsible for $45 \%$ of scientific works sent to Brazilian journals. ${ }^{15}$

As a result, Brazilian scientists end up breaking up robust works into articles with less impact, a phenomenon known as "salami slicing". Each discovery is sliced and published separately. The number of works increases, the discoveries remain similar, and the impact reduces. ${ }^{16}$

In order to measure the productivity of the impact of research groups, universities, countries and scientific journals, the h-index has been disseminated. By h-index, we understand an indicator proposed by the physicist Jorge Hirsch in 2005, to measure - at the same time - the productivity and the impact of a researcher's work, based in his or her most-cited articles. ${ }^{17}$

In the light of the data, it is worthwhile to problematize that in the years 2011 and 2012, citations of nursing did not occur in parallel with the rate of scientific production, it being the case that we observe fewer citations than would be expected. A more attentive look at the data reveals that publishing a scientific article does not always guarantee the divulging of the material.

The journals of the BRIC countries dedicate themselves little to the diffusion of the scientific knowledge published in their editions, resulting in an impasse between the interest of the author and of the journal in making public the information revealed through the scientific research in question.

The fact is that there is, on the part of the articles' authors, a growing interest that their publications should be cited by other researchers. On the other hand, although the journals, throughout their existences, have not paid attention explicitly to the need to divulge scientific production, they implicitly emphasize the importance of citations, in being evaluated and numbered in a ranking.
To a certain extent, the data indicates the publication per se is not able to meet the demand for public recognition. From the point of view of its production and context, scientific knowledge in the area of nursing remains, and fairly importantly, in the mind of the researcher. Obviously, although we have achieved great results in the search for the publication of nurses' scientific production, this is a huge challenge, to cite the knowledge which has already been published, which is extremely essential for scientific development.

Giving credit which goes beyond the professional skills and experiences regarding care provision, in evaluating the scientific knowledge produced by the researcher, there is a curricular valorisation, which emphasizes magnificently the development of scientific activities. We refer to performance indicators which use the citations of scientific articles as a basis.

We raise the example of the h-index, which proposes to quantify productivity and impact of scientists, based on their most-cited articles. ${ }^{17}$ It is able to measure quantity and quality of the academic production in a practical way; with a single number, one has a researcher's productivity and relevance. Such assessments are contributing to the improvement of the diffusion and production of scientific knowledge.

In analyzing the countries which make up the BRIC bloc, in relation to the h-index, we evidence that Brazil stands out, although all the countries in this group concern themselves with the h-index. Figure 1 illustrates this configuration.

For us to emphasize this indicator, it is worth emphasizing criticisms which the creator of the h-index himself makes: "A bibliometric indicator should always be used alongside other indicators, together with common sense".$^{18}$ Such criticisms result in reflections; one cannot use the h-index to compare researchers at different career stages. In this way, comparing the performance of researchers from different areas becomes a mistake.

We perceive that, as with other indicators which use citations of scientific articles as a basis, the h-index, once adopted, ends up influencing the publication culture of the different areas of knowledge in Brazil. This fact has gained credibility and status since the divulgation of a study undertaken by the University of São Paulo in 2011, which mapped the use of indexes of citations and bibliometric indicators in Brazilian scientific assessment. ${ }^{19}$ 


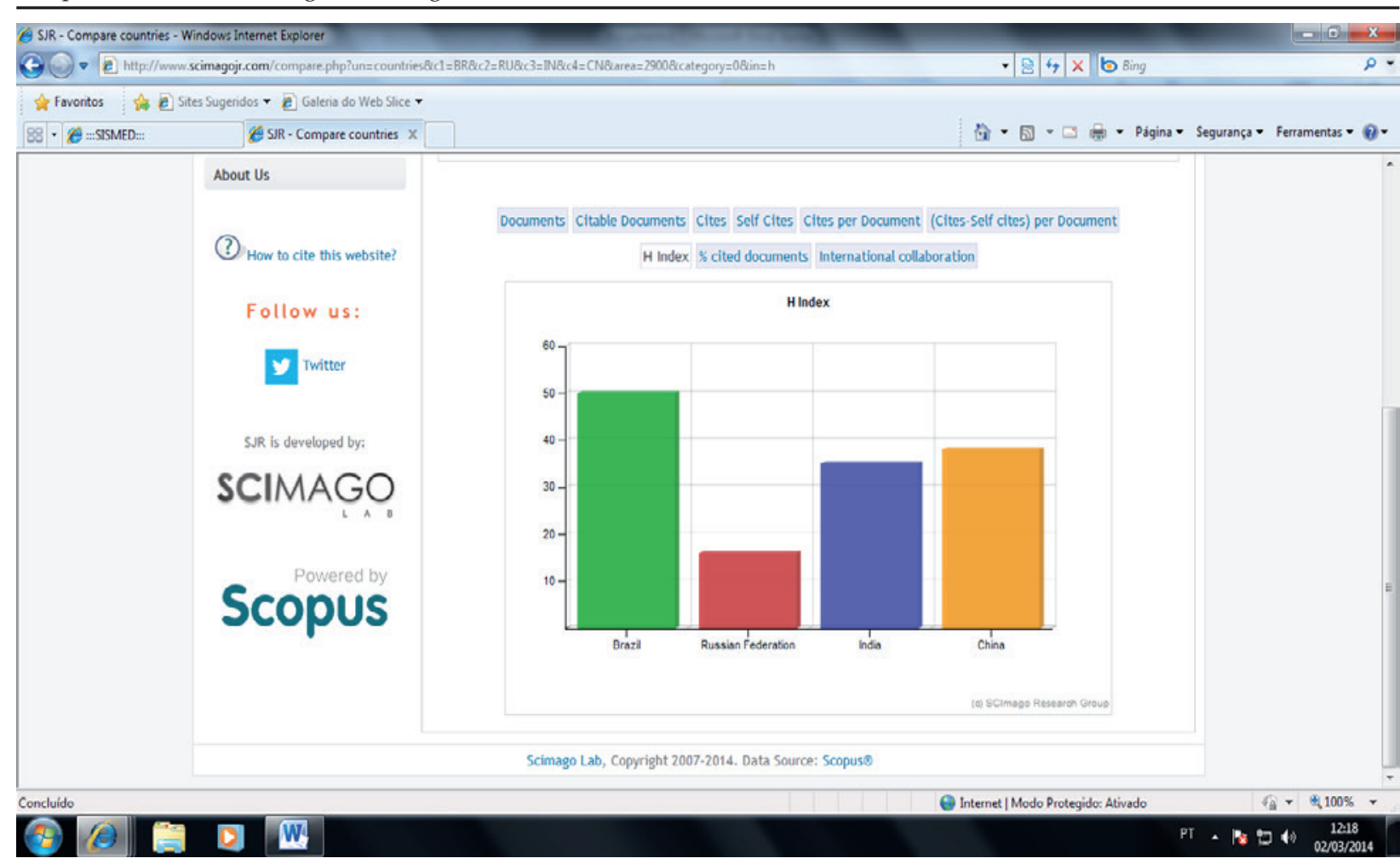

Source: SCImago Journal \& Country Rank.

Figure 1 - $\mathrm{H}$-index per country participating in BRIC

In the Qualis system, the Coordination for the Improvement of Higher Education Personnel (Capes) uses the h-index as one of the criteria for defining hierarchically the level of the scientific journals in different areas. Publications in journals ranked at a higher level end up having a greater weight in the assessment made by Capes, and, as a result, in order to ensure encouragement for their research, these journals become preferred by researchers.

In the area of nursing, journals with an hindex of at least 15 are guaranteed to be in the A1 strata. ${ }^{20}$ The growing pressure to make the knowledge acquired through scientific research available is evidenced, although major obstacles are observed to publishing in international journals, which has resulted in generating an extraordinary growth of journals in the field of the humanities in Brazil.

At the time of writing, Brazil has approximately 5,000 journals. The phenomena of the uncontrolled growth of journals in Brazil is evidenced by the growing number of postgraduate programs in the humanities. Emphasizing this, we report that the SciELO library receives requests for inclusion among which $80 \%$ are from journals from the area of the humanities. ${ }^{21}$

In the international scenario, in relation to the contribution of nursing production from the BRIC countries, we evidence that Russia $(77,778)$ is the country with the greatest prominent international contribution. On the other hand, China $(3,475)$, India $(20,755)$ and Brazil $(7,796)$, come in this order, with a slight difference, shown in table 3 , below.

Table 3 - International contribution by country participating in BRIC, 2012

\begin{tabular}{lrrrr}
\hline Year & Brazil & Russia & India & China \\
\hline 1996 & 33333 & 100000 & 20000 & 50000 \\
1997 & 73333 & 10000 & 16667 & 75000 \\
1998 & 50000 & 50000 & 23077 & 44444 \\
1999 & 43750 & 66667 & 26087 & 63636 \\
2000 & 18750 & - & 4000 & 66667 \\
2001 & 22222 & 100000 & 5000 & 78571 \\
2002 & 28571 & 60000 & 10417 & 33333 \\
2003 & 41935 & 66667 & 22222 & 64706 \\
2004 & 36923 & 100000 & 30303 & 68966 \\
2005 & 34831 & 100000 & 18750 & 72222 \\
2006 & 26205 & 50000 & 24706 & 14986 \\
2007 & 23593 & 66667 & 27273 & 15949 \\
2008 & 21951 & 83333 & 34146 & 20384 \\
2009 & 11596 & 54545 & 20879 & 25000 \\
2010 & 11731 & 50000 & 27879 & 23810 \\
2011 & 12137 & 77778 & 27027 & 26427 \\
2012 & 7796 & - & 20755 & 34750 \\
\hline
\end{tabular}

Source: SJR - SCImago Journal \& Country Rank. 
Russia, which in 2011 had 1.26 of growth referent to its scientific production in general, gains a position in the ranking for impact in 2012 referent to nursing. China has invested strongly in internationalization, but in relation to the specific area of nursing, major advances are not observed.

Brazil has tried to work on the concept that size and productivity go together. The quantitative leap in scientific articles in Brazil has taken place due to the efforts which have resulted in the institutional postgraduate infrastructure in recent decades.

For the research's impact, internationalization is decisive, evidenced by the articles produced by Brazilians, in the international collaboration, which have great prestige and end up being cited more. ${ }^{21}$ On the other hand, being published in international databases does not guarantee impact, the challenge being to internationalize the Brazilian journals themselves.

This being the case, it is essential that both the financing agencies and the universities support the national journals, given that the process of investigation and innovation is closely interlinked with scientific publication; this is one condition for the advance in Brazilian scientific production, without which we will never achieve the internationalization of the product of our studies.

Investing in strategies for attracting foreign authors to publish in Brazilian journals, as well as investing in the publication of works in English, are ways to favor Brazilian publishing, and when one refers to what can improve Brazilian research, in order to achieve a good impact, we bring the incentives to collaboration projects, which end by attracting foreign researchers. ${ }^{21}$

\section{CONCLUSION}

At the end of these reflections, we believe that we have raised contributions in the sense of enriching the discussions of the category. We evidence the need for the category to organize the production of knowledge, aiming not only to raise finances for its research, but, above all, to consolidate the body of knowledge of nursing.

We consider that we have achieved the objectives proposed; however, we recognize this work's limitations, in the sense that the issue requires a much more in-depth study. This being the case, we contemplate our reflections, as contributions to be added to those works which aim for the growth and consolidation of the research in our profession.
We emphasize that the issues treated here are complex and are far from being fully explored, our goal having been to form a critical perspective. The use of bibliometric indicators is necessary and extremely relevant for the creation of strategic actions related to the assessment and qualification of the scientific production of periodicals, researchers, institutions and countries.

We emphasize that the choice of a specific bibliometric indicator must be linked to the full awareness of its limitations, a fact very well made clear during the trajectory of our article. This is counterbalanced by the benefits of revealing patterns of research and identification of tendencies.

The use of resources made available in the SCImago database was shown to be interesting for the undertaking of studies of this type, providing a wide variety of avenues to be explored through later studies with analysis of other indicators.

\section{REFERENCES}

1. Base de Dados Tropical. Biodiversidade: perspectivas e oportunidades tecnológicas [página na Internet]. Campinas (SP): Fundação André Toseclo; 2005 [atualizado 2005 Agosto 22; acesso 2013 Nov 28]. [1 tela]. Disponível em: http://www.bdt.fat.org.br/ publicacoes/padct/bio/

2. Silva MB. A teoria da classificação facetada na modelagem de dados em banco de dados computacionais [tese]. João Pessoa (PB): Universidade Federal da Paraíba. Programa de Pós-Graduação em Ciência da Informação; 2011.

3. Ravelli APX, Fernandes GCM, Barbosa SFF, Simão E, Santos SMA, Meirelles BHS. A produção do conhecimento em enfermagem e envelhecimento: estudo bibliométrico. Texto Contexto Enferm. [online]. 2009 [acesso 2014 Jun 10]; 18(3). Disponível em: http:/ / www.scielo.br/scielo.php?script=sci_ arttext\&pid=S010407072009000300014

4. Vieira FV, Veríssimo MP. Crescimento econômico em economias emergentes selecionadas: Brasil, Rússia, Índia, China (BRIC) e África do Sul. Econ Soc. 2009 Nov-Dez; 18(37):513-46.

5. Marcias-Chapula CA. O papel da informetria e da cienciometria e sua perspectiva nacional e internacional. Ciênc Inf. 1998 Jan-Mar; 27 (2):134-40.

6. Hayashi MCPI, Hayashi CRM, Silva MR, Lima MY. Um estudo bibliométrico da produção científica sobre a educação jesuíta no Brasil colonial. Biblios 2007 Jul-Ago; 27 (1):1-18.

7. SCImago. SJR - SCImago Journal \& Country Rank. 2013 [acesso 2014 Mai 21]. Disponível em: http:// www.scimagojr.com 
8. Zancan GT. Educação científica: uma prioridade nacional. Perspec. 2002 Jul-Set; 14(3):167-70.

9. Mendes IAC. Pesquisa em enfermagem: impacto na prática. São Paulo (SP): Edusp; 1990.

10. Mendes IAC, Trevizan MA. The evolution of nursing research in Brazil. In: Fitzpatrick J, organizador. Annual review of nursing research. v.14. New York (US): Springer Publishing Company; 1996. p. 225-42.

11. Barreira IA. Pesquisa em enfermagem no Brasil e sua posição em agência federal de fomento. Rev LatinoAm Enfermagem 1993 Jan-Mar; 1(1):51-7.

12. Leite JL, Trezza MCS, Santos RM, Mendes IAC, Felli VEA. Os projetos de pesquisa em enfermagem no CNPq: seu percurso, suas temáticas, suas aderências. Rev Bras Enferm. 2001 Nov-Dez; 54(1):81-97.

13. UNESCO. Primary and education: age-specific enrolment ratios by gender 1960/61-1995/96 [página na Internet]. Paris (FR): Unesco; 1997 [atualizado 2005 Jun 04; acesso 2013 Julho 6]. Disponível em: http://unesdoc.unesco.org/ images/0010/001095/109560Eb.pdf

14. Meneghini R. Citations to papers from Brazilian institutions: a more effective indicator to assess productivity and the impact of research in graduate programs. Braz J Med Biol Res. 2011 Aug; 44(8):73847.

15. Hermes-Lima M, Santos NCF, Ferreira ST. Whither Latin America? Trends and challenges of science in
Latin America. IUBMB Life. 2007 Apr-May; 59(45):199-210.

16. Hermes-Lima M, Polcheira C, Trigueiro M, Beleboni R. Perceptions of Latin American scientists about science and post-graduate education: introduction to the 5th issue of CBP-Latin America. Comp Biochem Physiol A Mol Integr Physiol. 2008 Nov; 151(3):263-71.

17. Ruiz MA, Greco OT, Braile DM. Fator de impacto: importância e influência no meio editorial, acadêmico e científico. Rev Bras Cir Cardiovasc [online]. 2009 [acesso 2013 Out 16]; 24(3). Disponível em: http:// www.scielo.br/pdf/rbhh/v31n5/aop8209.pdf

18. Research Trends [http://www.researchtrends. com]. Holanda (NL): [atualizado 2009 Dezembro 01; acesso 2013 Nov 13]. Disponível em: http:// www.researchtrends.com/issue14-december-2009/ people-focus/

19. Meneghini R. Emerging journals. The benefits of and challenges for publishing scientific journals in and by emerging countries. EMBO Reports. 2012 Mar-Abr; 13(9):106-8.

20. Hirsch, JE. An index to quantify an individual's scientific research output. Proc Natl Acad Sci U S A. 2005 Nov 15; 102(46):16569-72.

21. Mugnaini R, Leite P, Leta J. Fontes de informação para análise de internacionalização da produção científica brasileira. PontodeAcesso. 2011 Fev-Mar; 5(11):87-102. 